The Jafanese Journal of Psychology

1973, Vol. 44, No. 4, 207-211

\title{
幼児の弁別逆転学習における負刺激機能
}

\author{
広島大学
}

\author{
羽生 義 正中塚 勝 俊

\section{FUNCTION OF NEGATIVE STIMULUS IN DISCRIMINATION REVERSAL LEARNING BY CHILDREN}

\author{
YOSHIMASA HABU AND KATSUTOSHI NAKATSUKA
}

Department of Psychology, Hiroshima University

\begin{abstract}
To determine the inhibitory effect of negative stimulus in discrimination learning, 91 preschool children were trained on shape discrimination. 4 groups received differential amounts of training in original learning. The effects were evaluated in terms of performance during reversal in which a new negative stimulus was introduced. A nonmonotonic function of the degree of original learning was found : the latency on the first reversal trial was longer for $S$ s with no original learning and for those overtrained, while it was shorter for those with intermediate degrees of original learning.
\end{abstract}

弁別学習あるいは, 正確には手掛り学習に特ける過剩 訓練効果 (ORE) を説明する試みが従来いろいろなされ てきている。その中で原学習に括ける負刺激（以下 Sとする）の制止特性ないし嫌徳性の機能を重視する立場 がある (D'Amato \& Jagoda, 1960, 1961 ; Biederman,

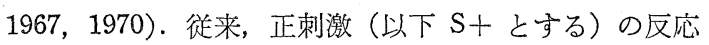
換起特性と S-の反応制止特性はともに, 訓練量の単調 増加関数として増大するという仮定が受け大られれてき た(Spence, 1936 ; Macphail, 1972). しかし, 上記の立 場はこの仮定にたいして疑問を投じた。すなわち，この 立場によると $S$ 一が帯びてくる反応制止特性は, 訓練量 の増加とともに, 訓練の初期かまたは中期までは增大す るが，それ以後はむしろ減少すると推測する。従って, このことより $\mathrm{S}$ 一の機能が訓練量の非単調関数となるこ とが仮定された。

このような仮説を実験的に検証する方法が，これまで いくつか試みられている. 以下これらの特質を簡単にふ りかえってみる。その一つは, D'Amato \& Jagoda (1961, 1962）らが使った方法であって，過剩訓練期にS一への 強制試行を何回か行わせ, そのことがのちの逆転学習に 括よぼす効果をみる。この方法は, 訓練量の関数として のS一の制止量を直接に抽き出すには不適当であろう. 2つめの方法は, Behar (1962) が用いたものである. 一種の WGTA を用いて, 120 個もの課題（立方体）を サルに解かせて, 各課題の訓練の直後に通常の試行間隔 を拉いて S十 または S一を中性刺激と対提示するテス ト試行を 1 回加えて, $S+$ $S$ - の重要性の変化を調

1 現香川大学
ベる、この方法は，陟児に適用する際，実際的な面で笑 施が困難であろう。3つめの方法は, Biederman ら (Deutsch \& Biederman, 1965, Biederman, 1967) に よる被験体内比較の方法である。この方法は，同一被験 体内で $\mathrm{S}$ 一の制止量の比較が可能であるという長所（こ の点は Behar の方法についても同じくいえる）がある 反面，いろいろの短所が指摘されている (Sutherland \& Mackintosh, 1971, Pp. 293-296 ; Berch, 1971).なか んづく, 訓練量と S一特性の間の関数の形を詳しく調べ るために, 同時に 3 つ以上の弁別課題を課すことは, 動 物にとってはもちろん，幼児にとっても容易なことでは ないと思われる。

いま1つの方法は，Mandler（1968）が彼女の実験に 特いて設けている 6 つの条件のうらの 1 つの条件である (C)の手続きを応用するものである. この方法は, 逆転 学習期に, 逆転第 1 試行めからなんらの予告や手掛りも 与えずに，新しく $S+$ となるべき旧 $S$ 一々今までに提示 されなかった新しい中性刺激 (S一) とを対にして提示す る. その他の点では原学習と同じ手続きである. 対提示 する刺激として中性刺激を使う手続さは Behar (1962) やBiederman (1967) の方法でも採られているが，それ らの方法と Mandler (1968) のそれとの違いは，後者で は逆転期を通して同一の中性刺激（結局はS一の特性を 帯びる）を提示する点である。テスト試行毎に異った刺 激を用いる場合の問題点は，その時提示された特定の刺 激の本来的な誘因価によって, 選択反応が影響を受け, そのためSーの特性の消長過程を検討するには不都合で あろう. その点 Mandler の方法は不都合がない. 
本研究では, Mandler の方法を用いた。従って の機能の主な指標は, 逆転当初に执ける反応潜時,すな わちいずれかの刺激を選択する反応の速さである．独立 変数は原学習の訓練量であって, その程度を 4 段階設 け，そのうら 1 段階は過剩訓練である. D'Amato や Biederman の立場から予想すると逆転当初に技ける新 $\mathrm{S}$ 一 への反応潜時は, 原学習の訓練量とともに, いった んは減少するが，のちにはとれとともに増大するであろ 5 .

ところで我々はさきに, 逆転当初に特ける新 $\mathrm{S}$ 一の選 択頻度，特よび逆転学習に括ける規準到達までの所要試 行数を主な指標とし, 規準群（連続 8 回正反応）と過剩 群（連続 20 回正反応）の条件差に誩いて, 前記の仮説 を検討したが，条件差よりむしろ，逆転前の全試行数の 大小によって，S一の抑制傾向が変化することを見いだ した（羽生・中塚，1971）。公こで本研究に执いては， 原学習の訓練段階を 4 段階に拡げ, それらが逆転学習に 特よぼす影響を検討した。

\section{方法}

被験者 広島市内のM括よびTという2 つの幼稚園の 園児 91 名を被験者とした。内訳は男児 47 名，女児 44 名である. 平均年齡は 6 オ 3 ケ月で各条件には無作為に わりあてられた。

装置と材料 1 辺が $20 \mathrm{~cm}$ の立方体の木製の箱を 1 対, カーテン 1 台, 強化因としてのビー玉・特はじき多 数と被験者が強化因を入れるための木製のケースを 1 個 使用した。1 対の箱にはそれぞれ全面に白紙がはってあ り，前面に刺激カードを插入する溝わくがついている. 反応潜時を測定するためのストップウォッチを 1 個使用 した。

刺激カード 横 $19 \mathrm{~cm}$, 縦 $23 \mathrm{~cm}$ の白い厭紙に図形が 描いてあるもの 3 枚（図形は内側をすべて黒くぬりつぶ した一辺が $11 \mathrm{~cm}$ の正三角形，一辺が $8.5 \mathrm{~cm}$ の正方 形, 直径が $9.5 \mathrm{~cm}$ の円）を用い，それらがカード中央 よりやや下部に描かれている.

実験条件 原学習の詶練量を以下の 4 通りに設定し た.すなわち，原学習を就こなわない群（“0 群”: 21 名), 連続 4 回正反応が生ずるまで原学習の訓練る括こ なら群 (“4 群”: 21 名), 連続 10 回正反応が生ずるま で訓練を叔こなら群（“10 回正反応群”：23 名）、执よび 連続 10 回正反応が生じたのち更に 15 試行だけ過剩訓 練を物こなら群（“10+15 回正反応群”：26 名）であっ た。これら 4 つの群に被験者をランダムにわりあてた.

手続き 1 . 原学習 三角形の描いてあるカードを正

2 予備実験の結果, ほとんどの被験者が円への選択偏 好を示したので，刺激図形による影響を少なくするた め, 一律に負刺激とした.
刺激, 円形の描いてあるカードを負刺激とした 2 . 各試 行で 1 対の箱のうち，1方の箱の下に男児にはビー玉を， 女児には特はじきをそれぞれ 1 個置いた。被験者は，強 化因がはいっていると思う方の箱を持ちあげてみる．正 反応であれば，強化因をとって手許のケースに溜める． 䛊反応の場合は，“はずれ”と言われるのみである。な 特正刺激はゲラマン系列により試行間で左右ランダムに なるように提示した.

2. 逆転学習 原学習時の負刺激 (円) を正刺激とし, 新たに正方形を負刺激とした。逆転到達規準はすべての 条件に特いて連続 10 回正反応とした.

3. 計時 被験者の前のカーテンを引き終ってから, 被験者がいずれか一方の箱を持らあげるまでの時間を実 験助手がストップウォッチで測定し，それを反応潜時と した。な沶カーテンの開閉方向はすべて一定とした.

4. 打切り 原学習, 逆転学習ともに 50 試行を経た のちにな技も規準未到達の場合は, 打切りとした。ただ し, 50 試行め直前から正反応が続いた場合は最高 59 試 行めまで継続することになる.

教示 特の搞のの群のいずれの被験者に対しても同様 な教示を与える。すなわち “これから先生とあてっこ遊 びをします。こちら (右側) があたりと思ったら、こち らの箱をるち岕げて下さい。こちら (左側) があたりと 思ったら，ごちらの箱をもらあげて下さい。“あたり’の 箱の下にだけビー玉 (男児のみ)・怙はじき（女児のみ） がはいっています。どららが‘あたり’かは，はじめの うちはよくわかりませんが，やっていくうちにわかるよ らになってきます。あたったとき“あたり’といいます から，続けて“あたり’といわ机るらに，よく見て， がんばって下さい”といら教示を与えた。ただし，こ の教示は 4 群, 10 群, $10+15$ 群の原学習, 0 群の逆転学 習の開始のときだけで，それ以後は与えない.

\section{結果}

習得過程 1 . 原学習 各群の原学習規準到達者の割 合 [到達者数/(未到達者数十到達者数)] 4 群 : $20 / 21$, 10 群: $14 / 23,10+15$ 群 : 19/26 であった。

2. 反応系列の分析 ある試行での正誤と, 次の試行 での選択刺激との連関が解決前にもすでに見いだされる と予想される. 10 群と $10+15$ 群の被験者のら占, 下記 のような反応系列のサンプルが取れるもの 14 名の反応 系列を標本として，この連関をみた。まず，原学習の初 期 11 試行については有意な連関はみられなかった。つ いで, 解決直前 11 試行（解決規準到達第 1 試行を含む） についてみると, 連関は有意であった $\left(\chi^{2}=20.41, d f=\right.$ $1, p<.01)$. その内容は, いわゆる win-stay, lose-shift の傾向, 即ち正反応の場合は次の試行でも直前の刺激と 同刺激を選択し，誤反応の場合は直前の刺激と反対の刺 激を選択する傾向であった。14 名の個人にるどってみる 
TABLE 1

$U$ tests on the number of trials to reversal criterion

\begin{tabular}{|c|c|c|c|c|}
\hline Groups & 0 & 4 & 10 & $10+15$ \\
\hline 0 & & $\begin{array}{l}U=59 \\
n=21, \quad 12\end{array}$ & $\begin{array}{l}U=134.5 \\
n=21, \quad 14\end{array}$ & $\begin{array}{l}U=193.5 \\
n=21, \quad 19\end{array}$ \\
\hline 4 & & & $\begin{array}{l}U=5^{*} \\
n=12, \quad 14\end{array}$ & $\begin{array}{l}U=4 * \\
n=12, \quad 19\end{array}$ \\
\hline 10 & & & & $\begin{array}{l}U=120.5 \\
n=14, \quad 19\end{array}$ \\
\hline
\end{tabular}

之, 明らかにこの反応傾向を示したとみられる人数は 8 名であった，win-stay の傾向は明りょらでないが loseshift を示したのが 2 名でこれを加えると合計 10 名が lose-shift の反応傾向を示していることになる，逆に lose-shift の傾向は明りょうでないが win-stay の傾向 を示したのは 1 名であった。即ち win-stay の反応傾向 を示しているのは合計 9 名である。これらのことは, 解 決規準到達值前には, 正刺激接近傾向と, 負刺激回避傾向 が同程度に発達していることを示唆するものである。な 晾, 正諨と位置反応との連関について調べた結果, 解決直 前に和いてそれは有意であった（ $\chi^{2}=5.34, d f=1, p<$ .05). 内容はlose-stay, win-shiftであり，興味深い結 果である.さらにさきの刺激についての分析結果で winstay, lose-shift を示したことがわかった 8 名のうち 4 名までが, 位置については lose-stay, win-shift を示し， 他の 4 名はそれぞれまちまらの反応傾向を示している。

逆転学習 各群の逆転プロパーの通過率は 0 群 : 16/ 21，4 群: 13/20, 10 群: 14/14, 10+15 群: 19/19 で あった。

1. 規準までの試行数 逆転学習の規準までの試行数 について各群を比較したのが Table 1 である. Table 1 の中の試行数には規準試行数 (10 試行) b含まれて持 り，0群および 4 群に括ける規準未到達者については, 試行数を一律に 50 試行として処理した。また 4 群では， 逆転規準到達までの試行数が 10 試行及び 11 試行とな った被験者 8 名は除いた。 というのは実験条件で意図し たごとく，4 群は原学習が未完成であることを前提に設 定し，その後の逆転学習の成績を吟味することであった ためである. 各群の所要試行数の範囲は 0 群 : 10-15, 4 群 : 13-50, 10 群: 10-16, 10+15 群 : 10-25 試行 であった．ただし多元比較のための修正を，Ryan (1960) の有意水準調整法によって特こなったところ，5\% 水準 で有意差が認められたのは，4 群一10 群間と，4 群一10 +15 群間のみであった。

2. 反応潜時 逆転第 1 試行に特ける反応潜時につい て各群を比較したのが Table 2であり，中央值によって 図示したのが Fig.1である.ここでも，前項の試行数の
TABLE 2

$U$ tests on the latency on the first trial following reversal

\begin{tabular}{|c|c|c|c|c|}
\hline Groups & 0 & 4 & 10 & $10+15$ \\
\hline 0 & & $\begin{array}{l}U=213.0^{*} \\
n=12,21\end{array}$ & $\begin{array}{l}U=267.5^{*} \\
n=14, \quad 21\end{array}$ & $\begin{array}{l}U=315.0^{*} \\
n=19, \quad 21\end{array}$ \\
\hline 4 & & & $\begin{array}{l}U=103.0^{* * *} \\
n=12, \quad 14\end{array}$ & $\begin{array}{l}U=159.0^{* *} \\
n=12, \quad 19\end{array}$ \\
\hline 10 & & & & $\begin{array}{l}U=181.0^{* *} \\
n=14,19\end{array}$ \\
\hline
\end{tabular}

分析に持けると同様な標本の選択を行なっている.

反応潜時の分析は, 各被験者の選択刺激とは無関係に 行なったが，各群の逆転第 1 試行に和ける旧負刺激の選 択頻度を参考のために示すと，0 群で 15/21，4 群で 2/ 12, 10 群で 3/14, $10+15$ 群で $3 / 19$ となっている. 0 群で頻度が高いのは, 注 2 で述べたことに対応して, 円 への偏好のためであろう. 残りの群に関しては, 頻度に 関する違いは無いといってよいだろう，として後述する ように，反応潜時はここでは新刺激と旧負刺激間の conflict の指標として測定されて抏り，問題は刺激提示 の時点から選択反応までの時間間隔であって, 特定選択 はさほど重要でほないと思われる，そこで，選択刺激と 無関係に反応潜時の分析をした。な执ここでも所要試行 数の分析で括こなわれたごとき修正を試みたが結果には 変化なく，Table 2 のと括りであった。

\section{考察}

原学習期について, 学習規準到達前の反応系列分析が 示すところによると, 少なくとも解決直前の諸試行に括 いては，単に不規則な試行錯誤より以上のbのがみられ る. 即ち, 正誤と選択刺激との連関では, 多くの被験者 が win-stay, lose-shift の傾向を示し, 正誤と選択位

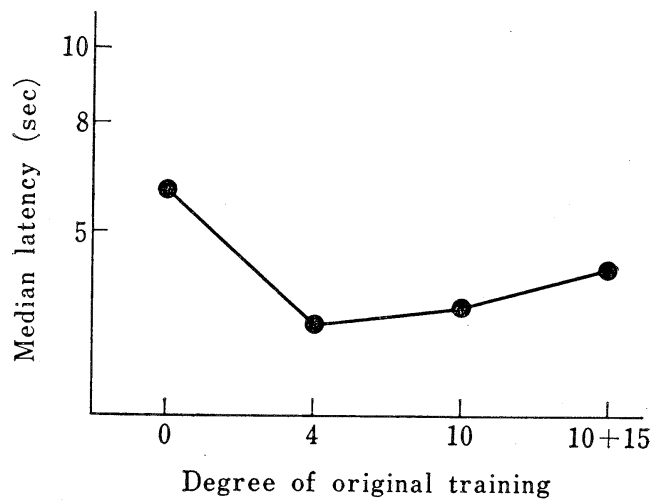

FIG. 1. Median latency on the first reversal trial for four groups. 
置との連関では, lose-stay, win-shift の傾向を示して いる.もっとも，場合によってはこれら 2 つの反応傾向 が同一個人の中で混在していることも示された。しかし ながら，学習のこの段階ではすでに，被験者たらはあた かもいくつかの解決策の間の選択特いて試行錯誤を行 なっているかのようである。

逆転期については，Table 2 と Fig. 1 から，原学習を 受けなかった群は, 逆転第 1 試行での反応時間が有意に 長く, 原学習を和こなった群の場合, その訓練量の増加 と共に反応時間が増大する傾向が伺える。これらの事実 は，Biederman の仮説を支持するものと考它られる. すなわち, 原学習の訓練量の増加と共に, 反応時間が, はじめのうちは減少し, ついで増大していることは訓練 量の増加とともに, S一の抑制量がはじめのうちは増大 し, ついで減少していることに対応する。というのは, 選択反応時間は他の条件が一定ならば, conflict 量に比 例するといってよい，そして旧 $\mathrm{S}$-（現 $\mathrm{S}+$ ）と新 $\mathrm{S}$ との間の conflict 量の程度は, 新 $\mathrm{S}$ 一 が中性であるか ら旧 S一の抑制傾向の大小のみによって決まり, それの 抑制傾向が増大すれば新 S一を，乙かもそれだけ短かい 選択反応時間でもって選択するであろうし，それが減少 すれば，新 S-との間の conflict 量が増大し，選択反 応時間は長くなるであろう，以上のことから上記の結果 は S一の抑制量が，Fig.1のグラフと水平な 1 つの対称 軸に関して線対称であるような, 訓練量の非単調な関数 となっていることを示唆しているように思われる。ただ しここで, 干渉要因として, 新 S一の新奇性（積極的又 は消極的）蛒よび S+からの刺激般化 (Berch，1971) が当然考えられる. 新奇性のほうは, 積極的な方向にし ろ, 消極的方向にしろ原学習の増大と共に増大するであ ろらから, 反応時間は原学習の増大とともに単調に減少 すると予想される，実験の結果は逆なので, 新奇性の効 果はここでは顕在化していないとみられる。また， $\mathrm{S}+$ からの刺激般化は，本実験では三角形（旧 $S+$ ) から正 方形 (新 $\mathrm{S}$-) への般化である. この要因もやはり, 原 学習の訓練量の増加に伴って増大するはずであるから, 新 S一への反応時間の減少となって現われるはずであ る。これも本実験の結果とは逆であるから，大きな要因 ではないといえよう。

\section{要 約}

幼児の弁別学習 (手掛り学習) に和ける負刺激の反応 抑制量が, 訓練の増加につれてどら変化するかを, 逆転 学習に拉いて新S一を導入する方法によって調べるのが 本研究の目的であった. 91 名の幼稚園児に原学習の訓 練量が 0 試行, 連続 4 試行正反応, 連続 10 試行正反応, 連続 $10+15$ 試行正反応の到達規準を持つ円 (一)一三角 形 $(+)$ の同時手別学習を課し，その後ひき続いて円 $(+)$
一四角形(一)の逆転学習を与えた。その結果, 逆転期に ついては（1）規準到達までの所要試行数に挌いては 4 試行連続正反応群が 10 試行群, $10+15$ 連続正反応群よ りも多く試行数を要した（Table 1).（2）反応潜時に和 いてはすべての群間に括いて有意差ないし差の傾向が認 められた。とりわけ 4 試行連続正反応群がもっとも短か い潜時を示した（Fig.1).な拈，原学習期については， 反応系列の分析の結果, 解決直前 11 試行の間で, 刺激 に関して win-stay, lose-shift の反応パターンが有意で あり, 15 名中, 10 名がこのような反応パターンを示し ていた.

\section{引用 文 献}

Behar, I. 1962 Evaluation of the significance of positional and negative cue in discrimination learning. Journal of Comparative and Physiological Psychology, 55, 502-504.

Berch, D. B. 1971 Comments on Biederman's "Continuity theory revisited : A failure in a basic assumption". Psychological Review, 78, 260-261.

Biederman, G. B. 1967 The overlearning reversal effect: A function of the nonmonotonicity of the negativity of $\mathrm{S}-$ during discriminative training. Psychonomic Science, 7, 385-386.

Biederman, G. B. 1970 Continuity theory revisited: A failure in a basic assumption. Psychological Review, 77, 255-256.

D’Amato, M. R., \& Jagoda, H. 1960 Effect of extinction trials on discrimination reversal. Journal of Experimental Psychology, 59, 254-260.

D’Amato, M. R., \& Jagoda, H. 1961 Analysis of the role of overlearning in discrimination reversal. Journal of Experimental Psychology, 61, 45-50.

D'Amato, M. R., \& Jagoda, H. 1962 Overlearning and position reversal. Journal of Experimental Psychology, 64, 117-122.

Deutsch, J. A., \& Biederman, G. B. 1965 The monotonicity of the negative stimulus during learning. Psychonomic Science, 3, 391-392.

羽生義正・中塚勝俊 1971 幼児の弁別学習に和ける負 刺激の機能 日本心理学会第 35 回大会発表論文集, Pp. 61-62.

Macphail, E. M. 1972 Inhibition in the acquisition and reversal of simultaneous discriminations. In R. A. Boakes \& M. S. Halliday (Eds.) Inhibition and learning. 121-151, New York : Academic Press.

Mandler, J. M. 1968 Overtraining and the use of positive and negative stimuli in reversal and transfer. Journal of Comparative and Physiological Psychology, 66, 110-115.

Ryan, T. A. 1960 Significance tests for multiple comparison of proportions, variances, and other 
statistics. Psychological Bulletin, 57, 318-328.

Spence, K. W. 1936 The nature of discrimination learning in animals. Psychological Review, 43, $427-449$.

Sutherland, N. S., \& Mackintosh, N. J. 1971 Mecha- nisms of animal discrimination learning. Academic Press, Pp. 293-296.

\section{SUMMARY}

The question raised is how the magnitude of inhibition in the negative stimulus changes with original training. Each of 91 preschool children was trained on a circle $(-)$-triangle $(+)$ simultaneous discrimination task. To determine the inhibitory effect gained during original training of various degrees upon reversal learning, we presented our subjects with the new stimulus (square) as the negative in reversal starting immediately after their reaching the following predetermined criteria for four groups :

Group $0 \cdots \cdots$ no original training

Group $4 \cdots \cdots 4$ consecutive correct responses

Group $10 \cdots \cdots 10$ consecutive correct responses

Group $10+15 \cdots \cdots 15$ additional trials following 10 consecutive correct responses.

The results were as follows:

(1) In the measure of number of trials to criterion during reversal, Group 4 took more trials than the other three groups (Table 1). This finding may give evidence contrary to the hypothesis of the 'all-or-none' type of discrimination learning in children.

(2) In terms of latency at the beginning of reversal, Group 0 took more time to respond than the other groups, while Group $10+15$ took slightly more time than Groups 4 and 10 (Fig. 1). This finding was discussed in relation to the nonmonotonic function hypothesized by Biederman (1967) concerning the negativity of a negative stimulus acquired after various degrees of original learning.

(3) The analysis of response sequence for Groups 10 and $10+15$ revealed that a 'winstay, lose-shift' type was significant with respect to stimulus during the latter portion of the presolution period of original learning ; many (10 out of 15) subjects showed this pattern of responding. 